OPEN ACCESS

Edited by:

Carla Maria Pedrosa Ribeiro, University of North Carolina at Chapel Hill, United States

Reviewed by: Catherine Greene, Royal College of Surgeons in Ireland, Ireland

Alexey Victorovich Sokolov, Institute of Experimental Medicine (RAS), Russia

*Correspondence: Judith A. Voynow judith.voynow@vcuhealth.org

Specialty section: This article was submitted to Inflammation Pharmacology, a section of the journal Frontiers in Pharmacology

Received: 28 May 2020 Accepted: 23 June 2020 Published: 08 July 2020

Citation:

Voynow JA, Zheng $S$ and Kummarapurugu $A B$ (2020)

Glycosaminoglycans as Multifunctional Anti-Elastase and Anti-Inflammatory Drugs in Cystic Fibrosis Lung Disease.

Front. Pharmacol. 11:1011. doi: 10.3389/fphar.2020.01011

\section{Glycosaminoglycans as Multifunctional Anti-Elastase and Anti-Inflammatory Drugs in Cystic Fibrosis Lung Disease}

\author{
Judith A. Voynow*, Shuo Zheng and Apparao B. Kummarapurugu \\ Department of Pediatric Pulmonology, Children's Hospital of Richmond at VCU, Richmond, VA, United States
}

Neutrophil elastase (NE) is a major protease in the airways of patients with cystic fibrosis (CF) that activates airway inflammation by several mechanisms. NE stimulates epithelial toll like receptors (TLR) resulting in cytokine upregulation and release, upregulates MUC5AC, a major airway mucin, degrades both phagocytic receptors and opsonins resulting in both neutrophil and macrophage phagocytic failure, generates oxidative stress via extracellular generation and uptake of heme free iron, and activates other proteases. Altogether, these mechanisms create a significant inflammatory challenge that impairs innate immune function and results in airway remodeling. Currently, a major gap in our therapeutic approach to CF lung disease is the lack of an effective therapeutic strategy targeting active $\mathrm{NE}$ and its downstream pro-inflammatory sequelae. Polysulfated glycosaminoglycans (GAGs) are potent anti-elastase drugs that have additional anti-inflammatory properties. Heparin is a prototype of a glycosaminoglycan with both anti-elastase and antiinflammatory properties. Heparin inhibits NE in an allosteric manner with high potency. Heparin also inhibits cathepsin $\mathrm{G}$, blocks P-selectin and L-selectin, hinders ligand binding to the receptor for advanced glycation endproducts, and impedes histone acetyltransferase activity which dampens cytokine transcription and High Mobility Group Box 1 release. Furthermore, nebulized heparin treatment improves outcomes for patients with chronic obstructive pulmonary disease (COPD), asthma, acute lung injury and smoke inhalation. However, the anticoagulant activity of heparin is a potential contraindication for this therapy to be developed for CF lung disease. Therefore, modified heparins and other GAGs are being developed that retain the anti-elastase and anti-inflammatory qualities of heparin with minimal to no anticoagulant activity. The modified heparin, 2-O, 3-O desulfated heparin (ODSH), maintains anti-elastase and antiinflammatory activities in vitro and in vivo, and has little residual anticoagulant activity. Heparan sulfate with $\mathrm{O}$-sulfate residues but not $\mathrm{N}$-sulfate residues blocks allergic asthmatic inflammation in a murine model. Polysulfated hyaluronic acid abrogates allergen- triggered rhinosinusitis in a murine model. Finally, nonsaccharide glycosaminoglycan mimetics with specific sulfate modifications can be designed to inhibit NE activity. Altogether, these novel GAGs or GAG mimetics hold significant 
promise to address the unmet need for inhaled anti-elastase and anti-inflammatory therapy for patients with CF.

Keywords: neutrophil elastase, cystic fibrosis, glycosaminoglycans, heparin, hyaluronic acid, High Mobility Group Box 1

\section{INTRODUCTION}

Cystic fibrosis (CF) lung disease is marked by recurrent exacerbations of acute bronchitis with an overexuberant inflammatory response and markedly high airway concentrations of neutrophil elastase (NE). A major gap in current therapy for patients with $\mathrm{CF}$ is the lack of anti-protease and anti-inflammatory therapies to inhibit NE and NE-activated sequelae. In this review, we will discuss the impact of NE on CF lung biology, review the current landscape of anti-protease and anti-inflammatory therapies for CF lung disease, and then discuss the biology and pharmacology of glycosaminoglycans (GAGs) as potential antiprotease and anti-inflammatory therapies for CF.

\section{Neutrophil Elastase and Cystic Fibrosis Lung Disease}

The primary defect in $\mathrm{CF}$, an autosomal recessive disorder, is the loss of function of the Cystic Fibrosis Transmembrane Conductance Regulator protein, which results in abnormal airway mucus (Stoltz et al., 2015; Boucher, 2019). CF airway mucus is tethered to submucosal ducts and airway epithelia (Ostedgaard et al., 2017; Ermund et al., 2018) with subsequent mucus stasis and failure to clear infections. Thus, recurrent cycles of infection and inflammation are established and neutrophils are recruited to the airway. In addition, mucus stasis alone may be sufficient to increase neutrophilic inflammation (Rosen et al., 2018), possibly by generating airway hypoxemic stress which triggers IL-1 $\beta$ and IL$1 \alpha$ cytokine release (Chen et al., 2019). The CF airway milieu, characterized by viscous sputum containing microbes and proinflammatory cytokines, further impairs neutrophil function and clearance (Voynow et al., 2008). Ultimately, in the CF airways, neutrophils release extracellular traps (Gray et al., 2018) or undergo necrosis (Vandivier et al., 2002), and release DNA and granule contents including proteases. The most abundant protease released into the CF airway is neutrophil elastase (NE).

$\mathrm{NE}$ is present in the bronchoalveolar lavage (BAL) fluid in infants with $\mathrm{CF}$, and BAL NE concentrations are directly associated with lung disease progression starting in infancy (Sagel et al., 2012; Sly et al., 2013; Rosenow et al., 2019). NE accelerates the progression of CF lung disease by several mechanisms (Voynow et al., 2008; McKelvey et al., 2019). First, NE contributes to altered ion flux in the CF airway by activating the epithelial sodium channel (Caldwell et al., 2005) and degrading CFTR via an endogenous proteinase, calpain (Le Gars et al., 2013). These NE actions further aggravate altered ion and water flux across the CF airway. Second, NE activates signaling pathways that promote abnormal epithelial structure and repair. NE upregulates mucin expression and goblet cell metaplasia (Voynow et al., 2004; Park et al., 2013); and triggers epithelial apoptosis (Suzuki et al., 2009) and/or premature senescence (Fischer et al., 2013), which impair epithelial proliferation and restoration following injury. Third, NE employs several mechanisms to promote airway inflammation (Voynow et al., 2008; Bruscia and Bonfield, 2016; Roesch et al., 2018). NE amplifies inflammation by upregulating neutrophil chemokines, e.g. IL-8 (Cosgrove et al., 2011), proteolytically activating chemokines such as IL-1 $\alpha$ or IL-33 (Clancy et al., 2018), and releasing damage associated molecular pattern proteins such as High Mobility Group Box 1 (HMGB1) (Griffin et al., 2014) which binds to the Receptor for Advanced Glycation End-products (RAGE) or facilitates ligand binding to TLR2 and TLR4 (Lotze and Tracey, 2005). NE further contributes to airway inflammation by increasing the expression of pro-inflammatory long chain ceramides (Karandashova et al., 2018; Horati et al., 2020); these lipids impact plasma membrane structure and receptor clustering. NE degrades innate immune proteins including lactoferrin and surfactant proteins A and D, and cleaves both complement and complement receptors causing impaired neutrophil and macrophage phagocytic activity (Voynow et al., 2008). NE increases the activity of other proteases; NE activates matrix metalloproteinase 9 (MMP 9) by cleavage of its prodomain and by degradation of its inhibitor, Tissue inhibitor of metalloprotease-1 (Jackson et al., 2010). In addition, the protease load is further exaggerated by the loss of endogenous anti-proteases. Anti-NE capacity is depleted in the CF airway due to NE degradation of elafin (Guyot et al., 2008), secretory leucoprotease inhibitor (Weldon et al., 2009; Twigg et al., 2015) and both oxidation and protease degradation of alpha-1- protease inhibitor (A1-PI) (Twigg et al., 2015). Finally, NE generates oxidative stress in epithelial cells and macrophages by degrading heme-containing proteins and releasing heme-free iron which is taken up by cells (Fischer et al., 2009); this process occurs in the airways of patients with CF (Ghio et al., 2013) and with COPD (Fischer et al., 2009). NE has a broad repertoire of activities that increase inflammation, impair host immunity and result in airway remodeling. Although NE appears to be a central regulator of inflammation in $\mathrm{CF}$ lung disease, $\mathrm{NE}$ actions are amplified by ligand-receptor interactions, oxidative stress, and the presence of other active proteases that contribute to a complex pro-inflammatory milieu. This may be one reason why the strategy of therapy for a single target, $\mathrm{NE}$ activity, in the $\mathrm{CF}$ airway, has not yet been successful.

\section{Status of Current Anti-Proteases and Anti- Inflammatory Therapies for Cystic Fibrosis}

Currently, there are two anti-inflammatory therapies approved for CF: azithromycin for patients with Pseudomonas aeruginosa infections (Nichols et al., 2020) and ibuprofen high dose oral 
therapy (Konstan et al., 1995). These therapies blunt the rate of decline of lung function over time; however, they do not resolve the high airway protease load that is associated with progression of bronchiectasis and lung injury. Many anti-protease candidate drugs have been tested in the CF airway (reviewed in (Voynow et al., 2008) and (Twigg et al., 2015)). An oral neutrophil elastase inhibitor, AZD9668, was tested in a Phase II randomized, double-blind, placebo-controlled trial in patients with CF (Elborn et al., 2012). Although AZD9668 treatment was associated with decreased urine desmosine, a marker of $\mathrm{NE}$ activity, and decreased sputum IL-6 and Regulated on Activation, Normal T Expressed and Secreted (RANTES), there was no improvement in sputum NE activity, sputum neutrophil counts, or measures of quality of life. A recent Phase IIa randomized, placebo-controlled clinical trial of inhaled alpha1 proteinase inhibitor (A1-HC) (Gaggar et al., 2016) revealed that the treatment group had increased sputum concentrations of A1$\mathrm{HC}$, but there was no significant change in lung function, quality of life measures, or sputum NE activity or sputum cytokine levels. Recently, an inhaled anti-NE therapy, POL6014, was studied in a Phase I trial using an ascending dose schedule in both healthy volunteers and participants with CF (Barth et al., 2019). A single inhaled dose was safe in both healthy volunteers and subjects with CF. Sputum active NE levels were reduced by greater than $1-\log$ at $3 \mathrm{~h}$ after treatment at all doses. Therapy with POL6014 for subjects with CF is currently being evaluated in a Phase IIa/IIb randomized, placebo-controlled, double-blind study (NCT03748199). This initial report of POL6014 activity is promising; however, there is still a compelling need to develop drugs with multifunctional anti-protease and anti-inflammatory activities that are resistant to protease degradation or oxidation.

\section{GAGs: Structure and Function}

GAGs are polymers composed primarily of disaccharides which consist of a D-glucosamine bound to either uronic acid (Dglucuronic acid or L-iduronic acid) or galactose (Morla, 2019). The composition and linkage of monosaccharides and addition of modifications define the four major classes of GAGs: heparin/ heparan sulfate (HS), chondroitin sulfate, dermatan sulfate, and hyaluronan. The uronic acid has a carboxylic acid unit and both monosaccharides are decorated with $\mathrm{N}$ - and O-linked sulfate residues that together confer a negative charge to the polymers. Native hyaluronan is not sulfated. In the CF lung, there are high levels of chondroitin sulfate and hyaluronan. Chondroitin sulfate proteoglycans contribute to turbidity and the mass of insoluble pellet in CF sputum; these qualities are relieved by depolymerization with chondroitinase ABC (Khatri et al., 2003). Low molecular weight hyaluronan may contribute to inflammation in the $\mathrm{CF}$ lung via TLR2 and TLR4 signaling and downstream NK- $\mathrm{KB}$ signaling (reviewed in (Reeves et al., 2011)). However, GAG structures can be modified to alter sulfation which plays a critical role in mediating biological effects. Moreover, GAG mimetics are being generated to achieve optimal drug characteristics while minimizing adverse properties. Heparin and HS proteoglycans bind to predicted basic amino acid-rich domains (Cardin and Weintraub, 1989; Hileman et al., 1998). GAGs have many biological effects that impact coagulation, infection, inflammation, cell adhesion, metastasis, cell matrix structure, and tissue differentiation and repair (Lima et al., 2017; Morla, 2019). Importantly, heparin can be taken up by cells and localized to cytoplasm and nucleus (Richardson et al., 2001; Raman et al., 2013) (Figure 1A). The localization of administered heparin to both extracellular and intracellular domains permits a wide array of anticipated functions including enzyme inhibition and interference with cell- cell receptor interactions, microbe- cell interactions, and HS proteoglycan pro-inflammatory activities. In this review, we will focus on GAG properties that impact CF and other chronic lung diseases.

\section{Modified Non-Anticoagulant Heparins and Anti-Inflammatory Activity}

Heparin is well known for its anticoagulant activity, but in addition, heparin has a broad repertoire of anti-inflammatory functions including anti-NE and anti-cathepsin G activity, inhibition of NF-kB, blockade of L- and P-selectin binding, and interference with HMGB1 release and interaction with its receptor, RAGE (Morla, 2019; Mulloy, 2019). At least three modified heparins have been developed to reduce anticoagulant activity but retain anti-inflammatory activity: glycolsplit heparin, sulfated-non-anticoagulant Low Molecular Weight Heparin (S- NACH) and 2-O, 3-O desulfated heparin (ODSH). Glycol-split heparin, generated by periodate oxidation of porcine mucosal heparin, is characterized by a cleavage between C2 and C3 of the nonsulfated uronic acid residue (Naggi et al., 2005). Glycol split heparin, administered subcutaneously to mice daily starting 10 days after establishment of chronic $P$. aeruginosa-agar bead pneumonia, decreases inflammatory cytokines, BAL neutrophil counts, and bacterial lung burden at 28 days (Lore et al., 2018). S-NACH is a purified fraction of low molecular weight heparin isolated to select drug with minimal anticoagulant activity (Shastri et al., 2015). In a murine asthma model generated by ovalbumin (OVA)-sensitization and challenge, S-NACH intraperitoneal administration following OVA challenge blunted BAL inflammation by eosinophils, macrophages, and neutrophils, blocked goblet cell metaplasia, and blocked $\mathrm{T} 2$ cytokine expression in serum and BAL (Ghonim et al., 2018).

Of the modified non-anticoagulant heparins tested for antiinflammatory efficacy, there is the most experience with 2-O, 3O, desulfated heparin (ODSH). Fryer et al. (1997) lyophilized heparin under alkaline condition to produce ODSH. ODSH has substantially reduced anticoagulant activity compared to heparin as determined by activated partial thromboplastin time (APTT) and anti-Xa clotting assays. But the anti-neutrophil protease activities, including anti-NE and anti-cathepsin $\mathrm{G}$ activities, are largely unchanged in ODSH compared to heparin. ODSH also retains the pharmacological properties of heparin in vivo, including inhibition of bronchial hyperreactivity after antigen challenge, and prevention of airway smooth muscle cell proliferation (Fryer et al., 1997). Importantly, ODSH does not bind to platelet factor 4 and thus doesn't trigger heparin-induced thrombocytopenia (Rao et al., 2010). ODSH interrupts ligandreceptor interactions, blunting pro-inflammatory signaling 

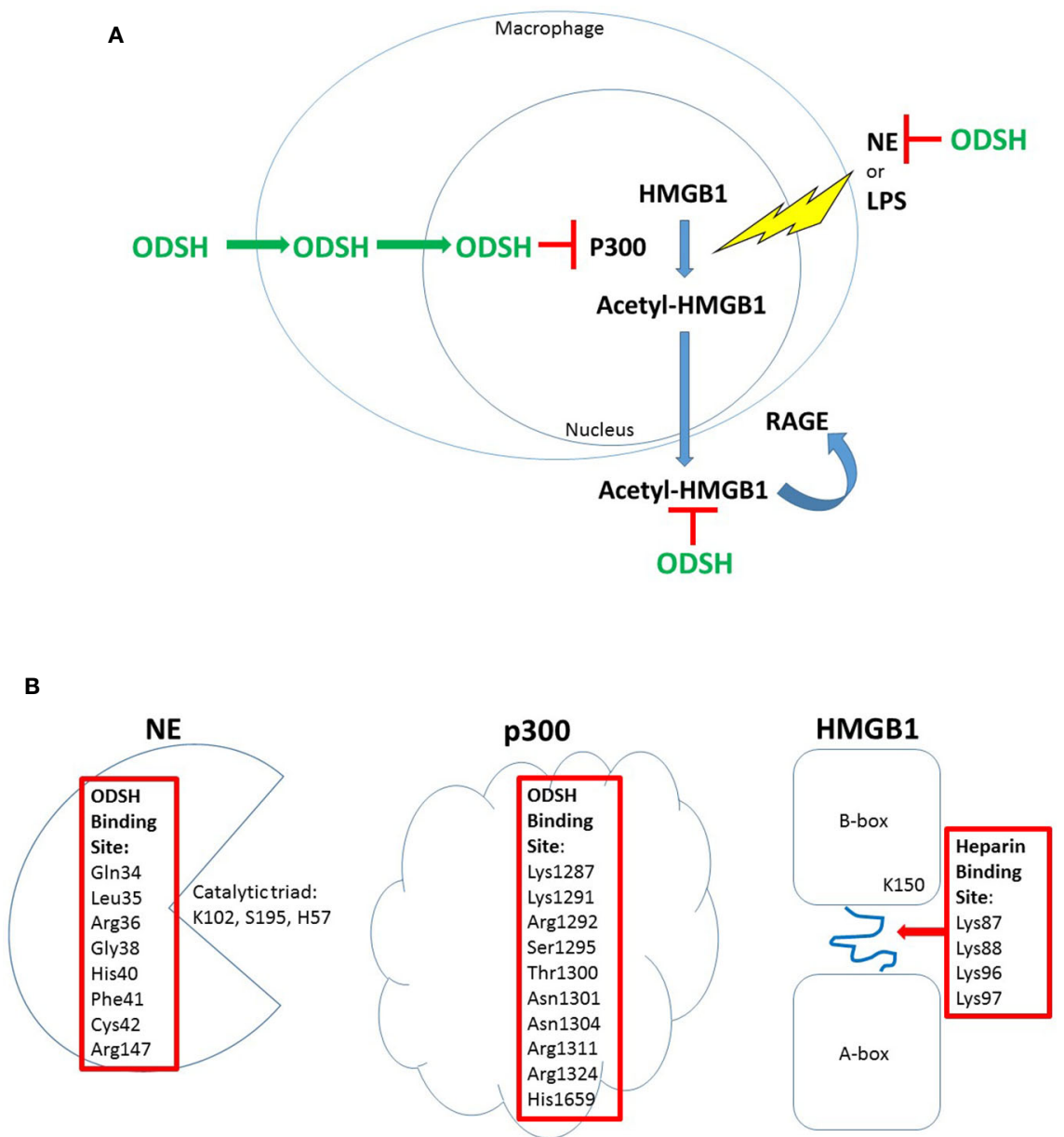

FIGURE 1 I ODSH localization and function in a macrophage cell line. ODSH is taken up by a mouse macrophage cell line (RAW264.7) into the cytoplasm within $2 \mathrm{~h}$ and into the nucleus by $24 \mathrm{~h}$ (Zheng et al., 2017) (A). ODSH has anti-NE activity and blocks HMGB1-RAGE interaction in the extracellular domain, and inhibits p300 lysine acetyltransferase activity in the nucleus (A). ODSH inhibits NE activity by binding to an allosteric inhibitory site (Kummarapurugu et al., 2018), and ODSH inhibits p300 enzyme activity by binding to the acetyl-CoA binding site in the catalytic domain (Zheng et al., 2017) (B). In contrast, ODSH binds to the loop connecting the A-box and B-box of HMGB1, blocking interaction with heparan sulfate proteoglycans required for HMGB1 ligation of the RAGE receptor (Xu et al., 2011) (B). Amino acid residues required for ODSH or heparin inhibitory activity are shown (Red Box).

cascades. Both heparin and ODSH inhibit RAGE- HMGB1 interaction and RAGE-S100A9/calgranulin interaction in vitro (Rao et al., 2010). The ODSH concentrations $\left(\mathrm{IC}_{50}\right)$ to inhibit NE activity $(0.14 \mu \mathrm{g} / \mathrm{ml})$, and to block HMGB1-RAGE binding $(0.23$ $\mu \mathrm{g} / \mathrm{ml}$ ) are similar, supporting the concept that ODSH (MW approximately $10 \mathrm{kD}$ ) achieves both anti-protease and antiinflammatory activities within a nanomolar concentration range.

\section{Heparin and ODSH Anti-HMGB1 Activity}

HMGB1 is recognized as a major inflammatory mediator in $\mathrm{CF}$ plasma and sputum that is strongly associated with lung disease progression (Liou et al., 2012; Chirico et al., 2015). Therefore, HMGB1 is likely to be an important target for CF antiinflammatory therapy. HMGB1 has two major functions; it is a nuclear non-histone chromatin binding protein that facilitates transcriptional regulation, and it is an extracellular damage associated molecule pattern or alarmin that is secreted by activated macrophages as a delayed mediator of inflammation (Lotze and Tracey, 2005). HMGB1 release is triggered by HMGB1 lysine acetylation which is activated following exposure to microbial products (LPS), cytokines (TNF $\alpha$ ) (Lotze and Tracey, 2005), or NE (Griffin et al., 2014). HMGB1 can also be released from necrotic cells. HMGB1 has been reported to transduce cellular signals by interacting with at least three receptors: RAGE, TLR2 and TLR4 (Park et al., 2004; Sharma et al., 2014). Binding of HMGB1 to RAGE activates NF$\kappa \mathrm{B}$ and the ERK/p38 pathway which promotes cytokine production (TNF, IL-6, and IFN- $\gamma$ ). Binding of HMGB1 to TLR2/TLR4 leads to NF- $\mathrm{KB}$ activation through a MyD88 (myeloid differentiation primary-response protein 88 )dependent mechanism. Importantly, ODSH blocks both HMGB1 release and HMGB1 ligation of receptors both in vitro and in vivo. Intratracheal HMGB1 in a mouse model induces significant pulmonary inflammation with increased BAL total 
cells, neutrophils, and TNF- $\alpha$ levels at $24 \mathrm{hr}$. Simultaneous intratracheal ODSH administered with HMGB1 decreased all of these BAL measures, indicating that ODSH can inhibit HMGB1-RAGE- induced inflammatory responses in vivo (Rao et al., 2010). A summary of glycol split heparin, S-NACH, and ODSH activities in vivo in preclinical models relevant to $\mathrm{CF}$ is summarized in Table $\mathbf{1}$.

ODSH is effective in preclinical models of infection and inflammation to blunt these pathologic processes. In a $P$. aeruginosa (PA)-induced murine pneumonia model, intranasal ODSH decreases BAL HMGB1 levels, reduces pulmonary bacterial burden, ameliorates PA-induced lung injury, and improves survival (Sharma et al., 2014). In a murine model of intratracheal NE-induced lung inflammation and remodeling, ODSH pretreatment blocks NE-induced neutrophil influx, upregulation of $\mathrm{KC}$, and release of $\mathrm{HMGB} 1$ into $\mathrm{BAL}$ (Griffin et al., 2014). To investigate the mechanism of ODSH inhibition of HMGB1 release, the impact of fluorescein-labeled (FITC)-ODSH on NE- or LPS-treated mouse macrophage cells (RAW264.7) was investigated. ODSH is taken up by RAW264.7 cells, and is localized to the cytoplasm and nucleus (Zheng et al., 2017). The sulfation pattern of modified heparins influence intracellular uptake and localization that is specific for different cell types (Raman et al., 2013). In RAW264.7 cells treated with NE or LPS, ODSH blocks HMGB1 lysine-acetylation in a dosedependent manner, by inhibiting P300 histone (lysine) acetyltransferase (HAT) activity. Spectrofluorometry reveals that ODSH binding to p300 results in a conformational change in p300, and further tightens ODSH-p300 binding; this mechanism is supported by a complementary approach of in silico modeling with combinatorial virtual library screening of interactions between p300 and ODSH (Zheng et al., 2017) (Figure 1B). Importantly, heparin also interacts directly with HMGB1, changing its conformation and reducing its affinity for RAGE which interrupts the HMGB1-RAGE signaling cascade (Ling et al., 2011). Furthermore, heparin and ODSH bind to NE and inhibit its activity.

\section{Heparin and ODSH Anti-NE Activity in Ex Vivo CF Sputum}

High concentrations of NE released by neutrophils are found in $\mathrm{CF}$ sputum. Importantly NE, a cationic serine protease, binds to the copious polyanionic polymers in sputum including DNA (Gray et al., 2015); mucins (Nadziejko and Finkelstein, 1994) and actin filaments (Broughton-Head et al., 2007; Kater et al., 2007). Dornase alfa (Fuchs et al., 1994) and 7\% hypertonic saline (HTS) (Elkins et al., 2006), the mainstay mucoactive therapies for patients with $\mathrm{CF}$, improve pulmonary function, and decrease the frequency of pulmonary exacerbations. However, both therapies have been reported to increase NE activity in CF sputum (Cantin, 1998; Chen et al., 2006). ODSH is a robust inhibitor of NE activity in vitro with a low $\mathrm{IC}_{50}$ (Griffin et al., 2014; Kummarapurugu et al., 2018), but in CF sputum, both $\mathrm{ODSH}$ and heparin inhibition of NE activity requires DNA depolymerization by DNase-1 (Kummarapurugu et al., 2018). This observation suggests that anionic DNA polymers compete with anionic ODSH for binding to NE. When these interactions were investigated, it was discovered by both pharmacokinetic studies and by combinatorial virtual library screening, that both DNA and ODSH bind to the same allosteric domain on NE that is required for inhibition (Kummarapurugu et al., 2018) (Figure 1B). Furthermore, inhibition of NE activity in sputum by heparin or DNA is chain length dependent, with a requirement for a larger size than approximately 15 monosaccharides for heparins (Spencer et al., 2006; Kummarapurugu et al., 2018) or 12-mer for DNA oligomers (Kummarapurugu et al., 2018). Neither fondiparinux, a heparin pentasaccharide $(1.8 \mathrm{kDa})$ nor a DNA hexamer have anti-NE activity, confirming that a threshold length is necessary for heparin and DNA to bind to NE and exert anti-elastase activity (Kummarapurugu et al., 2018). Interestingly, unfractionated heparin releases soluble DNA from sputum that is available for dornase alfa cleavage (Broughton-Head et al., 2007). Thus, heparin enhances DNase activity.

\section{Novel Glycosaminoglycan Therapeutics as Anti-Protease, Anti-Microbial, and/or Anti- Inflammatory Therapies}

Glycosaminoglycans have a broad array of functions both in native tissues and when modified to be used as competitors for endogenous heparan sulfate proteoglycans or for their properties to bind to cationic proteins and modify activities. Development of small synthetic non-saccharide glycosaminoglycan mimetics (NSGMs) offer modifiable alternatives for polysaccharide GAGs. NSGM 32 (Morla et al., 2019) has robust anti-elastase activity in vitro and has a mixed allosteric and orthosteric mechanism of action. However, NSGM 32 requires DNA depolymerization for anti-elastase activity in CF sputum, and is less potent than ODSH (Kummarapurugu et al., 2018). It was speculated that NSGM 32 binds to other positively charged moieties in CF sputum and therefore higher concentrations of drug are required for inhibition of NE activity (Morla et al., 2019). A sulfated synthetic lignin, sulfated dehydropolymer caffeic acid (CDSO3), inhibits the development of emphysema in a VEGFR-inhibitor-induced rat model via multiple functions including anti-oxidant activity, and prevention of epithelial and endothelial cell death via iron-chelation- induced stabilization of HIF- $1 \alpha$ and VEGF signaling (Truong et al., 2017). These two compounds illustrate the exquisite target specificity due to sulfation patterns incorporated into small synthetically produced GAG mimetics. Another advantage of synthetic sulfated lignins is that they are homogeneous compounds that do not require porcine or bovine bioproducts for production.

Polysulfated hyaluronan is a modified hyaluronic acid which has potent anti-inflammatory properties (Zhang et al., 2011). Low molecular weight polysulfated hyaluronan blocks LPS-stimulated macrophage release of cytokines including TNF $\alpha$, IL-6, IL-12, MCP-1, and increases expression of antioxidants, superoxide 2 and 3 (Jouy et al., 2017). In a murine model of second hand smoke induced lung disease, a polysulfated hyaluronan administered by intraperitoneal (i.p.) injection inhibits release of 
TABLE 1 | In vivo models of chronic lung diseases treated with modified or non-saccharide GAGs.

\begin{tabular}{|c|c|c|c|}
\hline Animal Model & $\begin{array}{c}\text { Treatment (Dose and } \\
\text { Administration) }\end{array}$ & Outcome Measures & Reference \\
\hline $\begin{array}{l}\text { Balb/c mice: } \\
\text { NE airway inflammation model } \\
\text { NE (o.a.) } \pm \text { ODSH (o.a.) }\end{array}$ & $\begin{array}{l}\text { Days } 1,4,7 \text { : } \\
\text { NE }(44 \mu \mathrm{M}) \text { or NS } \\
\text { ODSH }(635 \mu \mathrm{M}) \text { or NS o.a. } \\
\text { Day 8: BAL/lung harvest }\end{array}$ & $\begin{array}{l}\text { NE induces BAL cells \& PMN, KC, } \\
\text { HMGB1 } \\
\text { ODSH+NE: decreases total cells and } \\
\text { PMN; decreases KC and HMGB1 }\end{array}$ & Griffin et al. (2014) \\
\hline 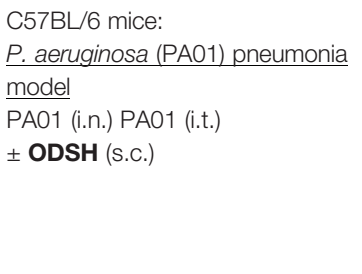 & $\begin{array}{l}\text { Day 1: PA01 i.n. } \\
\text { ODSH }(8.3-75 \mathrm{mg} / \mathrm{kg}) \text { or } \mathrm{NS} \\
\text { s.c. q } 12 \mathrm{~h} \times 2 \\
\text { Day 2: BAL/lung harvest } \\
\text { Day 1: PA01 i.t. } \\
\text { ODSH }(75 \mathrm{mg} / \mathrm{kg}) \text { or NS s.c. } 12 \\
\mathrm{~h} \times 4 \\
\text { Day 3: survival }\end{array}$ & $\begin{array}{l}\text { ODSH decreases PA01 CFU; } \\
\text { decreases lung protein content and } \\
\text { edema; decreases total and PMN cell } \\
\text { count; decreases BAL HMGB1; inhibits } \\
\text { TLR2 and TLR4 binding } \\
\text { ODSH improves mouse survival }\end{array}$ & Sharma et al. (2014) \\
\hline $\begin{array}{l}\text { C57Bl/6N } \\
\text { P.aeruginosa pneumonia model } \\
\text { (PA) CF isolate AA43- embedded } \\
\text { in agar beads (i.t.) } \\
\pm \text { glycol split LMWH, C3gs20 } \\
\text { vs. } \mathbf{N} \text {-acetyl LMWH, C23 s.c. }\end{array}$ & $\begin{array}{l}\text { Day 1: PA- agar beads }(1-2 \times \\
\left.10^{6}\right) \text { vs. sterile beads i.t. } \\
\text { Day 1-14: C3gs20 or } \mathbf{C 2 3} \text { (30 } \\
\text { mg/kg/d) or vehicle s.c. } \\
\text { Day 14: BAL and lung harvest } \\
\text { Day 1: PA- agar beads (1-2 x } \\
\left.10^{6}\right) \text { vs. sterile beads i.t. } \\
\text { Day 10-28: C3gs } 20 \text { or } \mathbf{C 2 3} \text { (30 } \\
\text { mg/kg/d) or vehicle s.c. } \\
\text { Day 28: BAL and lung harvest }\end{array}$ & $\begin{array}{l}\text { C23 decreased BAL total cells and } \\
\text { PMN; No significant change in PA CFU. } \\
\text { C3gs and } \mathbf{C 2 3} \text { decreased BAL total } \\
\text { cells and PMN, decreased total PA } \\
\text { CFU, and decreased IL-17A } \\
\text { C3gs20 decreased IL-1 } \beta \text {, IL-12pp40, } \\
\text { G-CSF, and KC }\end{array}$ & Lore et al. (2018) \\
\hline $\begin{array}{l}\text { C57BL/6J mice } \\
\text { Allergic Asthma model } \\
\text { OVA i.p. sensitization and } \\
\text { challenge with Ova } \pm \text { sulfated } \\
\text { non-anticoagulant LMWH (S- } \\
\text { NACH) i.p. }\end{array}$ & $\begin{array}{l}\text { Wk 1: Alum/Ova i.p.once per wk } \\
\text { x } 2 \\
\text { Wk 2-4: Ova 3\% inhaled 3x per } \\
\text { week } \\
\text { S-NACH }(10 \mathrm{mg} / \mathrm{kg}) \text { or NS i.p. } \\
\text { Week 5: BAL and lung harvest }\end{array}$ & $\begin{array}{l}\text { S-NACH decreased Ova-triggered } \\
\text { eosinophils, macrophages, lymphocytes } \\
\text { in BAL, decreased goblet cell } \\
\text { metaplasia, decreased lung tissue } \\
\text { hydroxyproline, decreased BAL and } \\
\text { serum T2 cytokines, decreased Ova- } \\
\text { lgE. }\end{array}$ & Ghonim et al. (2018) \\
\hline $\begin{array}{l}\text { C57BL/6 mice: } \\
\text { LL-37- induced rhinosinusitis } \\
\frac{\text { model }}{\text { LL37 i.n. } \pm \text { polysulfated HA }} \\
\text { (GM-0111) or HA i.n. }\end{array}$ & $\begin{array}{l}\text { Day 1: LL-37 }(115 \mu \mathrm{g}) \\
\text { GM-0111 or HA }(800 \mu \mathrm{g}) \text { Day 2: } \\
\text { sinus harvest }\end{array}$ & $\begin{array}{l}\text { LL-37 increases Mast cells, MPO, } \\
\text { lamina propria (LP) thickening and cell } \\
\text { death } \\
\text { GM-0111+LL-37: Decreased Mast } \\
\text { cells, MPO, LP thickening and cell } \\
\text { death } \\
\text { GM-0111 more effective than HA }\end{array}$ & Pulsipher et al. (2017) \\
\hline $\begin{array}{l}\text { BALB/c mice: } \\
\text { Aspergillus chronic rhinosinusitis } \\
\text { (CRS) model } \\
\text { A.fumigatus extract } \pm \\
\text { polysulfated HA (GM-1111) or } \\
\text { PBS } \\
\text { i.n. } \\
\text { 3 Groups: } \\
\text { 1. 1. PBS } \\
\text { 2. 2. A fumigatus+ PBS } \\
\text { 3. 3. A. fumigatus+ GM-1111 }\end{array}$ & $\begin{array}{l}\text { Week 0: } \\
\text { All groups sensitized with Alum + } \\
\text { PBS or A.fumigatus i.p. } \\
\text { Weeks 1-8: } \\
\text { PBS or A.fumigatus extract } \\
\text { (20,000 PNU i.n.) } 3 \text { x per wk. } \\
\text { Weeks 5-8: } \\
\text { PBS or GM-1111 (600 } \mu \mathrm{g}) \text { i.n.5x } \\
\text { per wk } \\
\text { Week 9: } \\
\text { Collect blood and sinonasal } \\
\text { tissue }\end{array}$ & $\begin{array}{l}\text { GM-1111+ A.fumigatus (Af) extract } \\
\text { decreased Af-induced CRS symptoms, } \\
\text { mucosal edema and injury, goblet cells, } \\
\text { TLR2 and TLR4, T2 cytokines, and lgE }\end{array}$ & Alt et al. (2018) \\
\hline $\begin{array}{l}\text { C57BL/6 mice } \\
\text { Second hand smoke model of } \\
\text { lung disease } \pm \text { sulfated } \\
\text { semisynthetic HA GAG ethers } \\
\text { (SAGEs) }\end{array}$ & $\begin{array}{l}\text { SHS vs. Rm air nasal inhalation } \\
10 \mathrm{~min} / \text { day x } 5 \mathrm{~d} / \mathrm{wk} \\
4 \text { weeks exposure } \\
\text { SAGE ( } 30 \mathrm{mg} / \mathrm{kg} \text { ) i.p. for } 3 \mathrm{~d} / \mathrm{wk} \\
\text { Collect BAL and lung RNA and } \\
\text { protein }\end{array}$ & $\begin{array}{l}\text { SAGEs effect on SHS exposure: } \\
\text { Blocked lung RAGE expression } \\
\text { Blocked BAL protein, total cells, and } \\
\text { cytokines: IL- } \alpha, \text { IL-2, TNF } \alpha\end{array}$ & Tsai et al. (2019) \\
\hline $\begin{array}{l}\text { Sprague Dawley rats } \\
\text { Rat Emphysema Model with } \\
\text { SU51416 (VEGFR inhibitor) } \pm\end{array}$ & $\begin{array}{l}\text { Day 1: } \\
\text { SU5416 }(20 \mathrm{mg} / \mathrm{kg}) \text { s.c. } \pm \\
\text { Day 1-Day 21: }\end{array}$ & $\begin{array}{l}\text { CDSO3 prevented SU5416-induced } \\
\text { emphysema, improved rat exercise } \\
\text { endurance, decreased oxidative stress, }\end{array}$ & Truong et al. (2017) \\
\hline
\end{tabular}


TABLE 1 | Continued

\begin{tabular}{|c|c|c|c|}
\hline Animal Model & $\begin{array}{l}\text { Treatment (Dose and } \\
\text { Administration) }\end{array}$ & Outcome Measures & Reference \\
\hline $\begin{array}{l}\text { polysulfated dehydropolymer } \\
\text { of caffeic acid (CDSO3) } \\
3 \text { Groups: } \\
\text { Untreated healthy } \\
\text { SU5416 + NS } \\
\text { SU5416 + CDSO3 }\end{array}$ & $\begin{array}{l}\text { CDSO3 }(60 \mu \mathrm{g} / \mathrm{kg}) \text { or NS inhaled } \\
\text { 3x per week }\end{array}$ & $\begin{array}{l}\text { and increased VEGF and HIF-1 } \alpha \text {, and } \\
\text { decreased cleaved caspase-3 }\end{array}$ & \\
\hline
\end{tabular}

BAL TNF $\alpha$, IL- $1 \alpha$, and IL-2, and decreases BAL inflammation and lung permeability (Tsai et al., 2019). A sulfated semisynthetic low molecular weight hyaluronan, GM-1111, (molecular weight $5.5 \mathrm{kD}$ ), has been tested for anti-inflammatory properties. In a mouse model of rhinosinusitis generated by intranasal administration of a cathelicidin fragment, LL37, GM-1111 blocks neutrophil and mast cell mucosal infiltration and significantly decreases epithelial apoptosis (Pulsipher et al., 2017). In vitro, in nasal epithelial cells, LL37 stimulates inflammation and cell death; another GM compound, GM-0111, inhibits IL-6 and IL-8 release and blocks Caspase-1- and Caspase-8 -induced cell death (Thomas et al., 2017). In an A.fumigatus- intranasal allergen-sensitization mouse model of chronic rhinosinusitis, intranasal GM-1111 introduced 3 weeks after A. fumigatus sensitization, significantly inhibits goblet cell metaplasia and mucosal T2 inflammation, and decreases TLR2 and TLR4 expression (Alt et al., 2018). In addition, in a periodontitis model, GM-0111 suppresses the growth of $P$. gingivalis and $A$. actinomycetemcomitans and biofilm formation, demonstrating antimicrobial activity (Savage et al., 2016). A summary of polysulfated hyaluronan activities in vivo in preclinical models of chronic lung disease is summarized in Table $\mathbf{1}$.

Heparan sulfate (HS) is expressed widely on many cell types as a proteoglycan. HS proteoglycans regulate inflammation by binding to ELR (Glu Leu Arg)- CXC chemokines at conserved His, Lys, Arg residues, controlling chemotactic gradients in the extracellular and pericellular matrices (Rajarathnam KaD, 2020). However, in the CF lung, endogenous HS proteoglycans have pro-inflammatory properties (Reeves et al., 2011); HS stabilizes cytokine and chemokine ligands, preventing protease digestion, thus increasing CXCL ligation to CXCR1 and 2 to upregulate inflammation (Rajarathnam KaD, 2020). HS enables RAGE hexamer formation for more efficient intracellular signaling (Xu et al., 2013), and binds L-selectin to promote neutrophil slowing and diapedesis across endothelial cells into tissues (Farrugia et al., 2018). HS also serves as a cell receptor for microbe adhesion and invasion (Rostand and Esko, 1997) (Figure 2). Bacteria, P. aeruginosa (Paulsson et al., 2019) and nontypable H. influenza (NTHi) (Su et al., 2019), and viruses, adenovirus (Dechecchi et al., 2001) and Severe Acute Respiratory Syndrome-Coronavirus (SARS-CoV) (Lang et al., 2011) and SARS-CoV-2 spike protein (So Young Kim et al., 2020) all bind to HS proteoglycans. Importantly, exposure to heparin competes with and inhibits binding to HS proteoglycans
(Figure 2) resulting in inhibition of binding of $P$. aeruginosa (Paulsson et al., 2019) and NTHi (Su et al., 2019) to laminin, a major component of the basal lamina in the airway, and inhibition of binding of adenovirus (Dechecchi et al., 2001) and SARS-CoV (Lang et al., 2011) to epithelia, and inhibition of SARS-CoV-2 (So Young Kim et al., 2020) spike protein to HS as detected by surface plasmon resonance. Treatment with synthetic HS or heparin inhibits cytokine/chemokine binding to G-protein coupled receptors and blocks neutrophil interaction with endothelial selectins resulting in decreased neutrophil influx (Lore et al., 2018) (Figure 2). Altered sulfation of HS affects provs anti-inflammatory behavior; increased $\mathrm{N}$ - and 6-O-sulfation increase cytokine ligation and neutrophil recruitment while increased 2-O-sulfation blunts neutrophilic inflammation (Axelsson et al., 2012). HS is also required for HMGB1-RAGE receptor binding; heparin can compete with $\mathrm{HS}$ and interrupt RAGE ligation by binding to HMGB1 (Xu et al., 2011).

\section{Clinical Trials Using GAGs for Respiratory Diseases}

Unfractionated heparin is the only GAG used in clinical trials to date. Inhaled heparin was tested in healthy volunteers and is safe and well tolerated. When delivered by nebulization, approximately $8 \%$ of the nebulized dose of heparin is delivered to the lower respiratory tract (Bendstrup et al., 1999). Importantly, inhaled doses up to $400,000 \mathrm{IU}$, did not affect lung function, but did increase circulating anti-Factor Xa activity and activated partial thromboplastin time (APTT) (Bendstrup et al., 2002). BAL fluid was tested for anti-coagulant activity in the presence of control plasma and by this method, the half-life of inhaled heparin was determined to be $28 \mathrm{~h}$ (Markart et al., 2010).

Inhalation of unfractionated heparin has been tested as a therapeutic for severe COPD (Shute et al., 2018), asthma (YildizPekoz and Ozsoy, 2017), smoke inhalation (Miller et al., 2014), and acute lung injury (ALI) (Dixon et al., 2010; Tuinman et al., 2012; Juschten et al., 2017), but the number of randomized, double-blind, placebo-controlled studies for these indications is limited (Table 2). There is one randomized, double- blind, placebo-controlled, crossover trial of twice daily inhaled heparin (50,000 IU per dose) for 2 weeks in adults with CF, which demonstrates a good safety profile, but does not show any significant improvement in lung function, sputum inflammatory markers or mucus clearance (Serisier et al., 2006). In contrast, a 


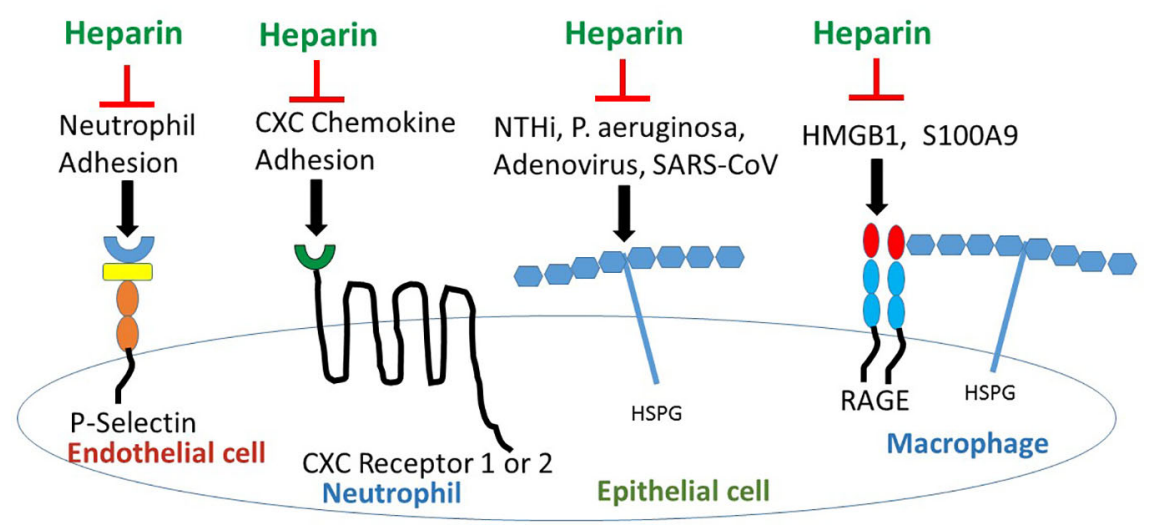

FIGURE 2 | Heparin/ODSH interrupts cell- cell interactions and ligand-receptor binding to block pro-inflammatory pathways. Heparin/ODSH oligosaccharides bind to P- and L-selectins and block neutrophil adhesion and chemotaxis (Nelson et al., 1993; Rao et al., 2010). Heparin inhibits CXCL8/IL-8 and other ELR (Glu Leu Arg)-CXC chemokines from binding to G-protein coupled receptors CXCR1 and CXCR2 (Rajarathnam KaD, 2020). Heparin competes with HSPG for binding to microbial proteins which prevents bacterial or viral-epithelial adhesion and invasion (Rostand and Esko, 1997). Heparin/ODSH bind to HMGB1 and S100A9 and interrupt RAGE ligation (Rao et al., 2010). HSPG, heparan sulfate proteoglycan; NTHi, non-typeable H. influenza; S100A9, calgranulin; SARS-CoV, Severe acute respiratory syndrome- corona virus.

randomized, double-blind, placebo-controlled single site study for COPD using twice daily inhaled heparin (150,000 IU per dose) in addition to inhaled twice daily salbutamol \& beclomethasone and airway clearance for 21 days reveals that heparin improves lung function including $\mathrm{FEV}_{1}, 6$ minute walk distance, and Borg dyspnea score (Shute et al., 2018). The contrast between the COPD study (Shute et al., 2018) and the previously cited CF study (Serisier et al., 2006) suggests that possible reasons for the failure of heparin to improve lung function in patients with CF were an insufficient dose of heparin and/or a limited trial duration to observe clinically significant changes in pulmonary function.

\section{SUMMARY}

There are many challenges for developing anti-protease and antiinflammatory drugs for patients with CF. The innate immune

TABLE 2 | Clinical trials using heparin for chronic lung diseases*.

\begin{tabular}{|c|c|c|c|c|}
\hline Disease & Trial design & Drug: dose and administration mode & Outcomes compared to placebo & Reference \\
\hline $\begin{array}{l}\text { Cystic } \\
\text { Fibrosis }\end{array}$ & $\begin{array}{l}\mathrm{R}, \mathrm{PC}, \mathrm{DB}-2 \text { weeks; } \\
\text { CF adults; moderate } \\
\text { to severe lung } \\
\text { disease; } \mathrm{N}=18\end{array}$ & Heparin $(50,000 \mathrm{U})$ inhaled every $12 \mathrm{~h}$ & $\begin{array}{l}\text { No change in } \mathrm{FEV}_{1} \\
\text { serum CRP } \\
\text { sputum IL-8, MPO, NE, TCC, } \\
\text { sputum volume }\end{array}$ & $\begin{array}{l}\text { Serisier } \\
\text { et al. } \\
(2006)\end{array}$ \\
\hline COPD & $\begin{array}{l}\text { R, PC, DB- } 3 \text { weeks; } \\
\text { COPD- GOLD II- IV; } \\
N=40\end{array}$ & Heparin $(75,000$ or 150,000 IU) Inhaled twice per day & $\begin{array}{l}\text { Adherence } 56 \% \\
\text { Improved FEV }_{1} \\
\text { Improved } 6 \mathrm{MWD} \\
\text { Increased } \mathrm{SpO} 2\end{array}$ & $\begin{array}{l}\text { Shute et al. } \\
(2018)\end{array}$ \\
\hline Asthma & $\begin{array}{l}\mathrm{R}, \mathrm{PC}, \mathrm{DB} \\
\text { crossover; Allergic to } \\
\text { dust mite; } \mathrm{N}=10\end{array}$ & $\begin{array}{l}\text { Heparin }(20,000 \mathrm{U}) \text { inhaled } 10 \text { min before inhaled dust mite extract } \\
\text { bronchoprovocation challenge }\end{array}$ & $\begin{array}{l}\text { Heparin increased the } \log _{2} \text { provocation } \\
\text { dose of dust mite protein nitrogen units } \\
\text { causing } 20 \% \text { fall in } \mathrm{FEV}_{1}\end{array}$ & $\begin{array}{l}\text { Bowler } \\
\text { et al. } \\
(1993)\end{array}$ \\
\hline Asthma & $\begin{array}{l}\mathrm{R}, \mathrm{PC}, \mathrm{DB} \\
\text { crossover; Allergic to } \\
\text { dust mite; } \mathrm{N}=8\end{array}$ & $\begin{array}{l}\text { Heparin (1000 U/kg/dose) inhaled: } 90 \text { min and } 30 \text { min pre-dust mite inhaled } \\
\text { challenge, and 2, 4, } 6 \text { h post-dust mite inhaled challenge }\end{array}$ & $\begin{array}{l}\text { Heparin blunted the severity of } \mathrm{FEV}_{1} \% \\
\text { decrease in late asthmatic responses } \\
\text { compared to placebo }\end{array}$ & $\begin{array}{l}\text { Diamant } \\
\text { et al. } \\
\text { (1996) }\end{array}$ \\
\hline $\begin{array}{l}\text { Asthma } \\
\text { EIB }\end{array}$ & $\begin{array}{l}\mathrm{R}, \mathrm{PC}, \mathrm{SB}, \text { cross- } \\
\text { over }-5 \text { days; } \\
\text { Asymptomatic; } \\
\mathrm{N}=12\end{array}$ & $\begin{array}{l}\text { Day 1: baseline PFT and exercise challenge; Day 3-5: Heparin (1000 U/kg) } \\
\text { or cromolyn ( } 20 \mathrm{mg}) \text { or placebo inhaled followed by exercise challenge }\end{array}$ & $\begin{array}{l}\text { Heparin blocks post-exercise decrease in } \\
\text { SGaw }\end{array}$ & $\begin{array}{l}\text { Ahmed } \\
\text { et al. } \\
\text { (1993) }\end{array}$ \\
\hline $\begin{array}{l}\text { Asthma } \\
\text { EIB }\end{array}$ & $\begin{array}{l}\mathrm{R}, \mathrm{PC}, \mathrm{DB}, \text { cross- } \\
\text { over }-7 \text { days; } \\
\text { Asymptomatic; } \mathrm{N}=13\end{array}$ & $\begin{array}{l}\text { Day 1: baseline PFT and exercise challenge; days 3-7: inhaled Heparin } \\
(80,0000 \mathrm{U}) \text { or Enoxaparin }(0.5,1,2 \mathrm{mg} / \mathrm{kg}) \text { or placebo } 45 \mathrm{~min} \text { before } \\
\text { baseline PFTs and then serially post-exercise }\end{array}$ & $\begin{array}{l}\text { Decrease in } \mathrm{FEV}_{1} \text { was blocked by heparin } \\
\text { and enoxaparin }\end{array}$ & $\begin{array}{l}\text { Ahmed } \\
\text { et al. } \\
\text { (1999) }\end{array}$ \\
\hline
\end{tabular}

*Only trials with randomized, double or single blind, placebo controlled design were included. 6MWD, 6 minute walk distance test; CRP, C-reactive protein; DB, double-blind; EIB, exerciseinduced bronchospasm; FEV 1 , Forced expiratory volume at 1 sec; MPO, myeloperoxidase; NE, neutrophil elastase; PC, placebo controlled; R, randomized; SB, single-blind; SGaw, Specific conductance of the airways; SpO2, oxyhemoglobin saturation; TCC, terminal complement complex. 
response is impaired for both viral (Zheng et al., 2003; Berkebile et al., 2020) and bacterial infections. The CF airway milieu is typified by high concentrations of several proteases including neutrophil serine proteases: NE, proteinase 3, Cathepsin G; lysosomal proteases: Cathepsins B, L, and S; and matrix metalloproteases: MMP-9, MMP-8 and MMP-12 (McKelvey et al., 2019) which stimulate downstream signaling cascades that perpetuate oxidative stress and inflammation. The strategy of directing therapy to one target is unlikely to be successful to control inflammation and prevent lung injury. Instead, we propose that GAGs can be developed and harnessed as multi-functional anti-elastase and anti-inflammatory therapies and serve an important function as part of the armamentarium for CF lung disease.

\section{REFERENCES}

Ahmed, T., Garrigo, J., and Danta, I. (1993). Preventing bronchoconstriction in exercise-induced asthma with inhaled heparin. N Engl. J. Med. 329, 90-95. doi: 10.1056/NEJM199307083290204

Ahmed, T., Gonzalez, B. J., and Danta, I. (1999). Prevention of exercise-induced bronchoconstriction by inhaled low-molecular-weight heparin. Am. J. Respir. Crit. Care Med. 160, 576-581. doi: 10.1164/ajrccm.160.2.9812076

Alt, J. A., Lee, W. Y., Davis, B. M., Savage, J. R., Kennedy, T. P., Prestwich, G. D., et al. (2018). A synthetic glycosaminoglycan reduces sinonasal inflammation in a murine model of chronic rhinosinusitis. PloS One 13, e0204709. doi: 10.1371/ journal.pone. 0204709

Axelsson, J., Xu, D., Kang, B. N., Nussbacher, J. K., Handel, T. M., Ley, K., et al. (2012). Inactivation of heparan sulfate 2-O-sulfotransferase accentuates neutrophil infiltration during acute inflammation in mice. Blood 120, 17421751. doi: 10.1182/blood-2012-03-417139

Barth, P., Bruijnzeel, P., Wach, A., Sellier Kessler, O., Hooftman, L., Zimmermann, J., et al. (2019). Single dose escalation studies with inhaled POL6014, a potent novel selective reversible inhibitor of human neutrophil elastase, in healthy volunteers and subjects with cystic fibrosis. J. Cyst. Fibros. 19, 299-304. doi: 10.1016/j.jcf.2019.08.020

Bendstrup, K. E., Chambers, C. B., Jensen, J. I., and Newhouse, M. T. (1999). Lung deposition and clearance of inhaled $(99 \mathrm{~m}) \mathrm{Tc}$-heparin in healthy volunteers. Am. J. Respir. Crit. Care Med. 160, 1653-1658. doi: 10.1164/ajrccm.160.5.9809123

Bendstrup, K. E., Gram, J., and Jensen, J. I. (2002). Effect of inhaled heparin on lung function and coagulation in healthy volunteers. Eur. Respir. J. 19, 606610. doi: 10.1183/09031936.02.00105202

Berkebile, A. R., Bartlett, J. A., Abou Alaiwa, M., Varga, S. M., Power, U. F., and McCray, P. B.Jr. (2020). Airway Surface Liquid Has Innate Antiviral Activity That Is Reduced in Cystic Fibrosis. Am. J. Respir. Cell Mol. Biol. 62, 104-111. doi: $10.1165 / \mathrm{rcmb} .2018-0304 \mathrm{OC}$

Boucher, R. C. (2019). Muco-Obstructive Lung Diseases. N Engl. J. Med. 380, 1941-1953. doi: 10.1056/NEJMra1813799

Bowler, S. D., Smith, S. M., and Lavercombe, P. S. (1993). Heparin inhibits the immediate response to antigen in the skin and lungs of allergic subjects. Am. Rev. Respir. Dis. 147, 160-163. doi: 10.1164/ajrccm/147.1.160

Broughton-Head, V. J., Shur, J., Carroll, M. P., Smith, J. R., and Shute, J. K. (2007). Unfractionated heparin reduces the elasticity of sputum from patients with cystic fibrosis. Am. J. Physiol. Lung Cell Mol. Physiol. 293, L1240-L1249. doi: 10.1152/ajplung.00206.2007

Bruscia, E. M., and Bonfield, T. L. (2016). Innate and Adaptive Immunity in Cystic Fibrosis. Clin. Chest Med. 37, 17-29. doi: 10.1016/j.ccm.2015.11.010

Caldwell, R. A., Boucher, R. C., and Stutts, M. J. (2005). Neutrophil elastase activates near-silent epithelial $\mathrm{Na}+$ channels and increases airway epithelial $\mathrm{Na}$ + transport. Am. J. Physiol. Lung Cell Mol. Physiol. 288, L813-L819. doi: 10.1152/ajplung.00435.2004

Cantin, A. M. (1998). DNase I acutely increases cystic fibrosis sputum elastase activity and its potential to induce lung hemorrhage in mice. Am. J. Respir. Crit. Care Med. 157, 464-469. doi: 10.1164/ajrccm.157.2.9608033

\section{AUTHOR CONTRIBUTIONS}

All authors wrote the text and edited the text. JV designed the figures.

\section{FUNDING}

We acknowledge the following support: Department of Defense grant PR180925, Cystic Fibrosis Foundation research grants, Voynow15I0 and Voynow19G0, and Commonwealth Health Research Board grant 236-14-14 (JV).

Cardin, A. D., and Weintraub, H. J. (1989). Molecular modeling of protein glycosaminoglycan interactions. Arteriosclerosis 9, 21-32. doi: 10.1161/ 01.ATV.9.1.21

Chen, Y., Hashiguchi, N., Yip, L., and Junger, W. G. (2006). Hypertonic saline enhances neutrophil elastase release through activation of $\mathrm{P} 2$ and $\mathrm{A} 3$ receptors. Am. J. Physiol. Cell Physiol. 290, C1051-C1059. doi: 10.1152/ajpcell.00216.2005

Chen, G., Sun, L., Kato, T., Okuda, K., Martino, M. B., Abzhanova, A., et al. (2019). IL-1beta dominates the promucin secretory cytokine profile in cystic fibrosis. J. Clin. Invest. 129, 4433-4450. doi: 10.1172/JCI125669

Chirico, V., Lacquaniti, A., Leonardi, S., Grasso, L., Rotolo, N., Romano, C., et al. (2015). Acute pulmonary exacerbation and lung function decline in patients with cystic fibrosis: high-mobility group box 1 (HMGB1) between inflammation and infection. Clin. Microbiol. Infect. 21, 368 e361-369. doi: 10.1016/j.cmi.2014.11.004

Clancy, D. M., Sullivan, G. P., Moran, H. B. T., Henry, C. M., Reeves, E. P., McElvaney, N. G., et al. (2018). Extracellular Neutrophil Proteases Are Efficient Regulators of IL-1, IL-33, and IL-36 Cytokine Activity but Poor Effectors of Microbial Killing. Cell Rep. 22, 2937-2950. doi: 10.1016/j.celrep.2018.02.062

Cosgrove, S., Chotirmall, S. H., Greene, C. M., and McElvaney, N. G. (2011). Pulmonary proteases in the cystic fibrosis lung induce interleukin 8 expression from bronchial epithelial cells via a heme/meprin/epidermal growth factor receptor/Toll-like receptor pathway. J. Biol. Chem. 286, 7692-7704. doi: 10.1074/jbc.M110.183863

Dechecchi, M. C., Melotti, P., Bonizzato, A., Santacatterina, M., Chilosi, M., and Cabrini, G. (2001). Heparan sulfate glycosaminoglycans are receptors sufficient to mediate the initial binding of adenovirus types 2 and 5. J. Virol. 75, 87728780. doi: 10.1128/JVI.75.18.8772-8780.2001

Diamant, Z., Timmers, M. C., van der Veen, H., Page, C. P., van der Meer, F. J., and Sterk, P. J. (1996). Effect of inhaled heparin on allergen-induced early and late asthmatic responses in patients with atopic asthma. Am. J. Respir. Crit. Care Med. 153, 1790-1795. doi: 10.1164/ajrccm.153.6.8665036

Dixon, B., Schultz, M. J., Smith, R., Fink, J. B., Santamaria, J. D., and Campbell, D. J. (2010). Nebulized heparin is associated with fewer days of mechanical ventilation in critically ill patients: a randomized controlled trial. Crit. Care 14, R180. doi: 10.1186/cc9286

Elborn, J. S., Perrett, J., Forsman-Semb, K., Marks-Konczalik, J., Gunawardena, K., and Entwistle, N. (2012). Efficacy, safety and effect on biomarkers of AZD9668 in cystic fibrosis. Eur. Respir. J. 40, 969-976. doi: 10.1183/09031936.00194611

Elkins, M. R., Robinson, M., Rose, B. R., Harbour, C., Moriarty, C. P., Marks, G. B., et al. (2006). A controlled trial of long-term inhaled hypertonic saline in patients with cystic fibrosis. $N$ Engl. J. Med. 354, 229-240. doi: 10.1056/NEJMoa043900

Ermund, A., Meiss, L. N., Dolan, B., Bahr, A., Klymiuk, N., and Hansson, G. C. (2018). The mucus bundles responsible for airway cleaning are retained in cystic fibrosis and by cholinergic stimulation. Eur. Respir. J.s 52, 1800457. doi: 10.1183/13993003.00457-2018

Farrugia, B. L., Lord, M. S., Melrose, J., and Whitelock, J. M. (2018). The Role of Heparan Sulfate in Inflammation, and the Development of Biomimetics as Anti-Inflammatory Strategies. J. Histochem. Cytochem. 66, 321-336. doi: $10.1369 / 0022155417740881$ 
Fischer, B. M., Domowicz, D. A., Zheng, S., Carter, J. L., McElvaney, N. G., Taggart, C., et al. (2009). Neutrophil elastase increases airway epithelial nonheme iron levels. Clin. Transl. Sci. 2, 333-339. doi: 10.1111/j.17528062.2009.00151.x

Fischer, B. M., Wong, J. K., Degan, S., Kummarapurugu, A. B., Zheng, S., Haridass, P., et al. (2013). Increased expression of senescence markers in cystic fibrosis airways. Am. J. Physiol. Lung Cell Mol. Physiol. 304, L394-L400. doi: 10.1152/ ajplung.00091.2012

Fryer, A., Huang, Y. C., Rao, G., Jacoby, D., Mancilla, E., Whorton, R., et al. (1997). Selective O-desulfation produces nonanticoagulant heparin that retains pharmacological activity in the lung. J. Pharmacol. Exp. Ther. 282, 208-219.

Fuchs, H. J., Borowitz, D. S., Christiansen, D. H., Morris, E. M., Nash, M. L., Ramsey, B. W., et al. (1994). Effect of aerosolized recombinant human DNase on exacerbations of respiratory symptoms and on pulmonary function in patients with cystic fibrosis. N. Engl. J. Med. 331, 637-642. doi: 10.1056/ NEJM199409083311003

Gaggar, A., Chen, J., Chmiel, J. F., Dorkin, H. L., Flume, P. A., Griffin, R., et al. (2016). Inhaled alpha1-proteinase inhibitor therapy in patients with cystic fibrosis. J. Cyst. Fibros. 15, 227-233. doi: 10.1016/j.jcf.2015.07.009

Ghio, A. J., Roggli, V. L., Soukup, J. M., Richards, J. H., Randell, S. H., and Muhlebach, M. S. (2013). Iron accumulates in the lavage and explanted lungs of cystic fibrosis patients. J. Cyst. Fibros. 12, 390-398. doi: 10.1016/ j.jcf.2012.10.010

Ghonim, M. A., Wang, J., Ibba, S. V., Luu, H. H., Pyakurel, K., Benslimane, I., et al. (2018). Sulfated non-anticoagulant heparin blocks Th2-induced asthma by modulating the IL-4/signal transducer and activator of transcription 6/Janus kinase 1 pathway. J. Transl. Med. 16, 243. doi: 10.1186/s12967-018-1621-5

Gray, R. D., McCullagh, B. N., and McCray, P. B. (2015). NETs and CF Lung Disease: Current Status and Future Prospects. Antibiot. (Basel) 4, 62-75. doi: 10.3390/antibiotics4010062

Gray, R. D., Hardisty, G., Regan, K. H., Smith, M., Robb, C. T., Duffin, R., et al. (2018). Delayed neutrophil apoptosis enhances NET formation in cystic fibrosis. Thorax 73, 134-144. doi: 10.1136/thoraxjnl-2017-210134

Griffin, K. L., Fischer, B. M., Kummarapurugu, A. B., Zheng, S., Kennedy, T. P., Rao, N. V., et al. (2014). 2-O, 3-O-desulfated heparin inhibits neutrophil elastase-induced HMGB-1 secretion and airway inflammation. Am. J. Respir. Cell Mol. Biol. 50, 684-689. doi: 10.1165/rcmb.2013-0338RC

Guyot, N., Butler, M. W., McNally, P., Weldon, S., Greene, C. M., Levine, R. L., et al. (2008). Elafin, an elastase-specific inhibitor, is cleaved by its cognate enzyme neutrophil elastase in sputum from individuals with cystic fibrosis. J. Biol. Chem. 283, 32377-32385. doi: 10.1074/jbc.M803707200

Hileman, R. E., Fromm, J. R., Weiler, J. M., and Linhardt, R. J. (1998). Glycosaminoglycan-protein interactions: definition of consensus sites in glycosaminoglycan binding proteins. Bioessays 20, 156-167. doi: 10.1002/ (SICI)1521-1878(199802)20:2<156::AID-BIES8 >3.0.CO;2-R

Horati, H., Janssens, H. M., Margaroli, C., Veltman, M., Stolarczyk, M., Kilgore, M. B., et al. (2020). Airway profile of bioactive lipids predicts early progression of lung disease in cystic fibrosis. J. Cyst. Fibros. doi: 10.1016/j.jcf.2020.01.010

Jackson, P. L., Xu, X., Wilson, L., Weathington, N. M., Clancy, J. P., Blalock, J. E., et al. (2010). Human neutrophil elastase-mediated cleavage sites of MMP-9 and TIMP-1: implications to cystic fibrosis proteolytic dysfunction. Mol. Med. 16, 159-166. doi: 10.2119/molmed.2009.00109

Jouy, F., Lohmann, N., Wandel, E., Ruiz-Gomez, G., Pisabarro, M. T., BeckSickinger, A. G., et al. (2017). Sulfated hyaluronan attenuates inflammatory signaling pathways in macrophages involving induction of antioxidants. Proteomics 17, el700082. doi: 10.1002/pmic.201700082

Juschten, J., Tuinman, P. R., Juffermans, N. P., Dixon, B., Levi, M., and Schultz, M. J. (2017). Nebulized anticoagulants in lung injury in critically ill patients-an updated systematic review of preclinical and clinical studies. Ann. Transl. Med. 5, 444. doi: 10.21037/atm.2017.08.23

Karandashova, S., Kummarapurugu, A., Zheng, S., Kang, L., Sun, S., Rubin, B. K., et al. (2018). Neutrophil elastase correlates with increased sphingolipid content in cystic fibrosis sputum. Pediatr. Pulmonol. 53, 872-880. doi: 10.1002/ ppul.24001

Kater, A., Henke, M. O., and Rubin, B. K. (2007). The role of DNA and actin polymers on the polymer structure and rheology of cystic fibrosis sputum and depolymerization by gelsolin or thymosin beta 4. Ann. N Y Acad. Sci. 1112, 140-153. doi: 10.1196/annals.1415.006
Khatri, I. A., Bhaskar, K. R., Lamont, J. T., Sajjan, S. U., Ho, C. K. Y., and Forstner, J. (2003). Effect of chondroitinase ABC on purulent sputum from cystic fibrosis and other patients. Pediatr. Res. 53, 619-627. doi: 10.1203/01.PDR. 0000054780.11755.B9

Konstan, M. W., Byard, P. J., Hoppel, C. L., and Davis, P. B. (1995). Effect of highdose ibuprofen in patients with cystic fibrosis. $N$ Engl. J. Med. 332, 848-854. doi: 10.1056/NEJM199503303321303

Kummarapurugu, A. B., Afosah, D. K., Sankaranarayanan, N. V., Navaz Gangji, R., Zheng, S., Kennedy, T., et al. (2018). Molecular principles for heparin oligosaccharide-based inhibition of neutrophil elastase in cystic fibrosis. J. Biol. Chem. 293, 12480-12490. doi: 10.1074/jbc.RA118.002644

Lang, J., Yang, N., Deng, J., Liu, K., Yang, P., Zhang, G., et al. (2011). Inhibition of SARS pseudovirus cell entry by lactoferrin binding to heparan sulfate proteoglycans. PloS One 6, e23710. doi: 10.1371/journal.pone.0023710

Le Gars, M., Descamps, D., Roussel, D., Saussereau, E., Guillot, L., Ruffin, M., et al. (2013). Neutrophil elastase degrades cystic fibrosis transmembrane conductance regulator via calpains and disables channel function in vitro and in vivo. Am. J. Respir. Crit. Care Med. 187, 170-179. doi: 10.1164/ rccm.201205-0875OC

Lima, M., Rudd, T., and Yates, E. (2017). New Applications of Heparin and Other Glycosaminoglycans. Molecules 22 (5), 749. doi: 10.3390/molecules22050749

Ling, Y., Yang, Z. Y., Yin, T., Li, L., Yuan, W. W., Wu, H. S., et al. (2011). Heparin changes the conformation of high-mobility group protein 1 and decreases its affinity toward receptor for advanced glycation endproducts in vitro. Int. Immunopharmacol. 11, 187-193. doi: 10.1016/j.intimp.2010.11.014

Liou, T. G., Adler, F. R., Keogh, R. H., Li, Y., Jensen, J. L., Walsh, W., et al. (2012). Sputum biomarkers and the prediction of clinical outcomes in patients with cystic fibrosis. PloS One 7, e42748. doi: 10.1371/journal.pone.0042748

Lore, N. I., Veraldi, N., Riva, C., Sipione, B., Spagnuolo, L., De Fino, I., et al. (2018). Synthesized Heparan Sulfate Competitors Attenuate Pseudomonas aeruginosa Lung Infection. Int. J. Mol. Sci. 19 (1), 207. doi: 10.3390/ijms19010207

Lotze, M. T., and Tracey, K. J. (2005). High-mobility group box 1 protein (HMGB1): nuclear weapon in the immune arsenal. Nat. Rev. Immunol. 5, 331-342. doi: 10.1038/nri1594

Markart, P., Nass, R., Ruppert, C., Hundack, L., Wygrecka, M., Korfei, M., et al. (2010). Safety and tolerability of inhaled heparin in idiopathic pulmonary fibrosis. J. Aerosol. Med. Pulm. Drug Delivery 23, 161-172. doi: 10.1089/jamp.2009.0780

McKelvey, M. C., Weldon, S., McAuley, D. F., Mall, M. A., and Taggart, C. C. (2019). Targeting Proteases in Cystic Fibrosis Lung Disease: Paradigms, Progress, and Potential. Am. J. Respir. Crit. Care Med. 201, 141-147. doi: 10.1164/rccm.201906-1190PP

Miller, A. C., Elamin, E. M., and Suffredini, A. F. (2014). Inhaled anticoagulation regimens for the treatment of smoke inhalation-associated acute lung injury: a systematic review. Crit. Care Med. 42, 413-419. doi: 10.1097/CCM. ob013e3182a645e5

Morla, S., Sankaranarayanan, N. V., Afosah, D. K., Kumar, M., Kummarapurugu, A. B., Voynow, J. A., et al. (2019). On the Process of Discovering Leads That Target the Heparin-Binding Site of Neutrophil Elastase in the Sputum of Cystic Fibrosis Patients. J. Med. Chem. 62, 5501-5511. doi: 10.1021/acs.jmedchem. $9 \mathrm{~b} 00379$

Morla, S. (2019). Glycosaminoglycans and Glycosaminoglycan Mimetics in Cancer and Inflammation. Int. J. Mol. Sci. 20, 5501-5511. doi: 10.3390/ ijms 20081963

Mulloy, B. (2019). The non-anticoagulant promise of heparin and its mimetics. Curr. Opin. Pharmacol. 46, 50-54. doi: 10.1016/j.coph.2019.03.009

Nadziejko, C., and Finkelstein, I. (1994). Inhibition of neutrophil elastase by mucus glycoprotein. Am. J. Respir. Cell Mol. Biol. 11, 103-107. doi: 10.1165/ ajrcmb.11.1.7912511

Naggi, A., Casu, B., Perez, M., Torri, G., Cassinelli, G., Penco, S., et al. (2005). Modulation of the heparanase-inhibiting activity of heparin through selective desulfation, graded $\mathrm{N}$-acetylation, and glycol splitting. J. Biol. Chem. 280, 12103-12113. doi: 10.1074/jbc.M414217200

Nelson, R. M., Cecconi, O., Roberts, W. G., Aruffo, A., Linhardt, R. J., and Bevilacqua, M. P. (1993). Heparin oligosaccharides bind L- and P-selectin and inhibit acute inflammation. Blood 82, 3253-3258. doi: 10.1182/ blood.V82.11.3253.3253

Nichols, D. P., Odem-Davis, K., Cogen, J. D., Goss, C. H., Ren, C. L., Skalland, M., et al. (2020). Pulmonary Outcomes Associated with Long-Term Azithromycin 
Therapy in Cystic Fibrosis. Am. J. Respir. Crit. Care Med. 201, 430-437. doi: 10.1164/rccm.201906-1206OC

Ostedgaard, L. S., Moninger, T. O., McMenimen, J. D., Sawin, N. M., Parker, C. P., Thornell, I. M., et al. (2017). Gel-forming mucins form distinct morphologic structures in airways. Proc. Natl. Acad. Sci. U.S.A. 114, 6842-6847. doi: 10.1073/pnas.1703228114

Park, J. S., Svetkauskaite, D., He, Q., Kim, J. Y., Strassheim, D., Ishizaka, A., et al. (2004). Involvement of toll-like receptors 2 and 4 in cellular activation by high mobility group box 1 protein. J. Biol. Chem. 279, 7370-7377. doi: 10.1074/ jbc.M306793200

Park, J. A., Sharif, A. S., Shiomi, T., Kobzik, L., Kasahara, D. I., Tschumperlin, D. J., et al. (2013). Human neutrophil elastase-mediated goblet cell metaplasia is attenuated in TACE-deficient mice. Am. J. Physiol. Lung Cell Mol. Physiol. 304, L701-L707. doi: 10.1152/ajplung.00259.2012

Paulsson, M., Su, Y. C., Ringwood, T., Udden, F., and Riesbeck, K. (2019). Pseudomonas aeruginosa uses multiple receptors for adherence to laminin during infection of the respiratory tract and skin wounds. Sci. Rep. 9, 18168. doi: 10.1038/s41598-019-54622-z

Pulsipher, A., Qin, X., Thomas, A. J., Prestwich, G. D., Oottamasathien, S., and Alt, J. A. (2017). Prevention of sinonasal inflammation by a synthetic glycosaminoglycan. Int. Forum Allergy Rhinol. 7, 177-184. doi: 10.1002/alr.21865

Rajarathnam KaD, U. R. (2020). Structural Insights Into How Proteoglycans Determine Chemokine-CXCR1/CXCR2 Interactions: Progress and Challenges. Front. Immunol. 11, 660. doi: 10.3389/fimmu.2020.00660

Raman, K., Mencio, C., Desai, U. R., and Kuberan, B. (2013). Sulfation patterns determine cellular internalization of heparin-like polysaccharides. Mol. Pharm. 10, 1442-1449. doi: 10.1021/mp300679a

Rao, N. V., Argyle, B., Xu, X., Reynolds, P. R., Walenga, J. M., Prechel, M., et al. (2010). Low anticoagulant heparin targets multiple sites of inflammation, suppresses heparin-induced thrombocytopenia, and inhibits interaction of RAGE with its ligands. Am. J. Physiol. Cell Physiol. 299, C97-110. doi: 10.1152/ajpcell.00009.2010

Reeves, E. P., Bergin, D. A., Murray, M. A., and McElvaney, N. G. (2011). The involvement of glycosaminoglycans in airway disease associated with cystic fibrosis. ScientificWorldJournal 11, 959-971. doi: 10.1100/tsw.2011.81

Richardson, T. P., Trinkaus-Randall, V., and Nugent, M. A. (2001). Regulation of heparan sulfate proteoglycan nuclear localization by fibronectin. J. Cell Sci. 114, 1613-1623.

Roesch, E. A., Nichols, D. P., and Chmiel, J. F. (2018). Inflammation in cystic fibrosis: An update. Pediatr. Pulmonol. 53, S30-S50. doi: 10.1002/ppul.24129

Rosen, B. H., Evans, T. I. A., Moll, S. R., Gray, J. S., Liang, B., Sun, X., et al. (2018). Infection Is Not Required for Mucoinflammatory Lung Disease in CFTRKnockout Ferrets. Am. J. Respir. Crit. Care Med. 197, 1308-1318. doi: 10.1164/ rccm.201708-1616OC

Rosenow, T., Mok, L. C., Turkovic, L., Berry, L. J., Sly, P. D., Ranganathan, S., et al. (2019). The cumulative effect of inflammation and infection on structural lung disease in early cystic fibrosis. Eur. Respir. J. 54, 1801771. doi: 10.1183/ 13993003.01771-2018

Rostand, K. S., and Esko, J. D. (1997). Microbial adherence to and invasion through proteoglycans. Infect. Immun. 65, 1-8. doi: 10.1128/IAI.65.1.1-8.1997

Sagel, S. D., Wagner, B. D., Anthony, M. M., Emmett, P., and Zemanick, E. T. (2012). Sputum biomarkers of inflammation and lung function decline in children with cystic fibrosis. Am. J. Respir. Crit. Care Med. 186, 857-865. doi: 10.1164/rccm.201203-0507OC

Savage, J. R., Pulsipher, A., Rao, N. V., Kennedy, T. P., Prestwich, G. D., and Ryan, M. E. (2016). Lee WY. A Modified Glycosaminoglycan, GM-0111, Inhibits Molecular Signaling Involved in Periodontitis. PloS One 11, e0157310.

Serisier, D. J., Shute, J. K., Hockey, P. M., Higgins, B., Conway, J., and Carroll, M. P. (2006). Inhaled heparin in cystic fibrosis. Eur. Respir. J. 27, 354-358. doi: 10.1183/09031936.06.00069005

Sharma, L., Wu, J., Patel, V., Sitapara, R., Rao, N. V., and Kennedy, T. P. (2014). Mantell LL. Partially-desulfated heparin improves survival in Pseudomonas pneumonia by enhancing bacterial clearance and ameliorating lung injury. J. Immunotoxicol. 11, 260-267. doi: 10.3109/1547691X.2013.839587

Shastri, M. D., Stewart, N., Horne, J., Zaidi, S. T., Sohal, S. S., Peterson, G. M., et al. (2015). Non-Anticoagulant Fractions of Enoxaparin Suppress Inflammatory Cytokine Release from Peripheral Blood Mononuclear Cells of Allergic Asthmatic Individuals. PloS One 10, e0128803. doi: 10.1371/journal.pone.0128803
Shute, J. K., Puxeddu, E., and Calzetta, L. (2018). Therapeutic use of heparin and derivatives beyond anticoagulation in patients with bronchial asthma or COPD. Curr. Opin. Pharmacol. 40, 39-45. doi: 10.1016/j.coph.2018.01.006

Shute, J. K., Calzetta, L., Cardaci, V., di Toro, S., Page, C. P., and Cazzola, M. (2018). Inhaled nebulised unfractionated heparin improves lung function in moderate to very severe COPD: A pilot study. Pulm. Pharmacol. Ther. 48, 8896. doi: 10.1016/j.pupt.2017.10.001

Sly, P. D., Gangell, C. L., Chen, L., Ware, R. S., Ranganathan, S., Mott, L. S., et al. (2013). Risk factors for bronchiectasis in children with cystic fibrosis. New Engl. J. Med. 368, 1963-1970. doi: 10.1056/NEJMoa1301725

So Young Kim, W. J., Sood, A., Montgomery, D. W., Grant, O. C., Fuster, M. M., $\mathrm{Fu}$, L., et al. (2020). Glycosaminoglycan binding motif at S1/S2 proteolytic cleavage site on spike glycoprotein may facilitate novel coronavirus (SARSCoV-2) host cell entry. PloS Pathog. doi: 10.1101/2020.04.14.041459

Spencer, J. L., Stone, P. J., and Nugent, M. A. (2006). New insights into the inhibition of human neutrophil elastase by heparin. Biochemistry 45, 91049120. doi: 10.1021/bi060338r

Stoltz, D. A., Meyerholz, D. K., and Welsh, M. J. (2015). Origins of cystic fibrosis lung disease. $N$ Engl. J. Med. 372, 351-362. doi: 10.1056/NEJMra1300109

Su, Y. C., Mattsson, E., Singh, B., Jalalvand, F., Murphy, T. F., and Riesbeck, K. (2019). The Laminin Interactome: A Multifactorial Laminin-Binding Strategy by Nontypeable Haemophilus influenzae for Effective Adherence and Colonization. J. Infect. Dis. 220, 1049-1060. doi: 10.1093/infdis/jiz217

Suzuki, T., Yamashita, C., Zemans, R. L., Briones, N., Van Linden, A., and Downey, G. P. (2009). Leukocyte elastase induces lung epithelial apoptosis via a PAR-1-, NF-kappaB-, and p53-dependent pathway. Am. J. Respir. Cell Mol. Biol. 41, 742-755. doi: 10.1165/rcmb.2008-0157OC

Thomas, A. J., Pulsipher, A., Davis, B. M., and Alt, J. A. (2017). LL-37 causes cell death of human nasal epithelial cells, which is inhibited with a synthetic glycosaminoglycan. PloS One 12, e0183542. doi: 10.1371/journal.pone.0183542

Truong, T. M., Li, H., Dhapare, S., Desai, U. R., Voelkel, N. F., and Sakagami, M. (2017). Sulfated dehydropolymer of caffeic acid: In vitro anti-lung cell death activity and in vivo intervention in emphysema induced by VEGF receptor blockade. Pulm. Pharmacol. Ther. 45, 181-190. doi: 10.1016/j.pupt. 2017.06.007

Tsai, K. Y. F., Hirschi Budge, K. M., Llavina, S., Davis, T., Long, M., Bennett, A., et al. (2019). RAGE and AXL expression following secondhand smoke (SHS) exposure in mice. Exp. Lung Res. 45, 297-309. doi: 10.1080/01902148.2019.1684596

Tuinman, P. R., Dixon, B., Levi, M., Juffermans, N. P., and Schultz, M. J. (2012). Nebulized anticoagulants for acute lung injury - a systematic review of preclinical and clinical investigations. Crit. Care 16, R70. doi: 10.1186/cc11325

Twigg, M. S., Brockbank, S., Lowry, P., FitzGerald, S. P., Taggart, C., and Weldon, S. (2015). The Role of Serine Proteases and Antiproteases in the Cystic Fibrosis Lung. Mediators Inflammation 2015, 293053. doi: 10.1155/2015/293053

Vandivier, R. W., Fadok, V. A., Hoffmann, P. R., Bratton, D. L., Penvari, C., Brown, K. K., et al. (2002). Elastase-mediated phosphatidylserine receptor cleavage impairs apoptotic cell clearance in cystic fibrosis and bronchiectasis. J. Clin. Invest. 109, 661-670. doi: 10.1172/JCI0213572

Voynow, J. A., Fischer, B. M., Malarkey, D. E., Burch, L. H., Wong, T., Longphre, M., et al. (2004). Neutrophil elastase induces mucus cell metaplasia in mouse lung. Am. J. Physiol. Lung Cell Mol. Physiol. 287, L1293-L1302. doi: 10.1152/ ajplung.00140.2004

Voynow, J. A., Fischer, B. M., and Zheng, S. (2008). Proteases and cystic fibrosis. Int. J. Biochem. Cell Biol. 40, 1238-1245. doi: 10.1016/j.biocel.2008.03.003

Weldon, S., McNally, P., McElvaney, N. G., Elborn, J. S., McAuley, D. F., Wartelle, J., et al. (2009). Decreased levels of secretory leucoprotease inhibitor in the Pseudomonas-infected cystic fibrosis lung are due to neutrophil elastase degradation. J. Immunol. 183, 8148-8156. doi: 10.4049/jimmunol.0901716

Xu, D., Young, J., Song, D., and Esko, J. D. (2011). Heparan sulfate is essential for high mobility group protein 1 (HMGB1) signaling by the receptor for advanced glycation end products (RAGE). J. Biol. Chem. 286, 41736-41744. doi: 10.1074/jbc.M111.299685

Xu, D., Young, J. H., Krahn, J. M., Song, D., Corbett, K. D., Chazin, W. J., et al. (2013). Stable RAGE-heparan sulfate complexes are essential for signal transduction. ACS Chem. Biol. 8, 1611-1620. doi: 10.1021/cb4001553

Yildiz-Pekoz, A., and Ozsoy, Y. (2017). Inhaled Heparin: Therapeutic Efficacy and Recent Formulations. J. Aerosol. Med. Pulm. Drug Delivery 30, 143-156. doi: 10.1089/jamp.2015.1273 
Zhang, J., Xu, X., Rao, N. V., Argyle, B., McCoard, L., Rusho, W. J., et al. (2011). Novel sulfated polysaccharides disrupt cathelicidins, inhibit RAGE and reduce cutaneous inflammation in a mouse model of rosacea. PloS One 6, e16658. doi: 10.1371/journal.pone.0016658

Zheng, S., De, B. P., Choudhary, S., Comhair, S. A., Goggans, T., Slee, R., et al. (2003). Impaired innate host defense causes susceptibility to respiratory virus infections in cystic fibrosis. Immunity 18, 619-630. doi: 10.1016/S1074-7613(03)00114-6

Zheng, S., Kummarapurugu, A. B., Afosah, D. K., Sankaranarayanan, N. V., Boothello, R. S., Desai, U. R., et al. (2017). 2-O, 3-O Desulfated Heparin Blocks High Mobility Group Box 1 Release by Inhibition of p300 Acetyltransferase Activity. Am. J. Respir. Cell Mol. Biol. 56, 90-98. doi: 10.1165/rcmb.2016-0069OC
Conflict of Interest: The authors declare that the research was conducted in the absence of any commercial or financial relationships that could be construed as a potential conflict of interest.

Copyright (c) 2020 Voynow, Zheng and Kummarapurugu. This is an open-access article distributed under the terms of the Creative Commons Attribution License (CC BY). The use, distribution or reproduction in other forums is permitted, provided the original author(s) and the copyright owner(s) are credited and that the original publication in this journal is cited, in accordance with accepted academic practice. No use, distribution or reproduction is permitted which does not comply with these terms. 